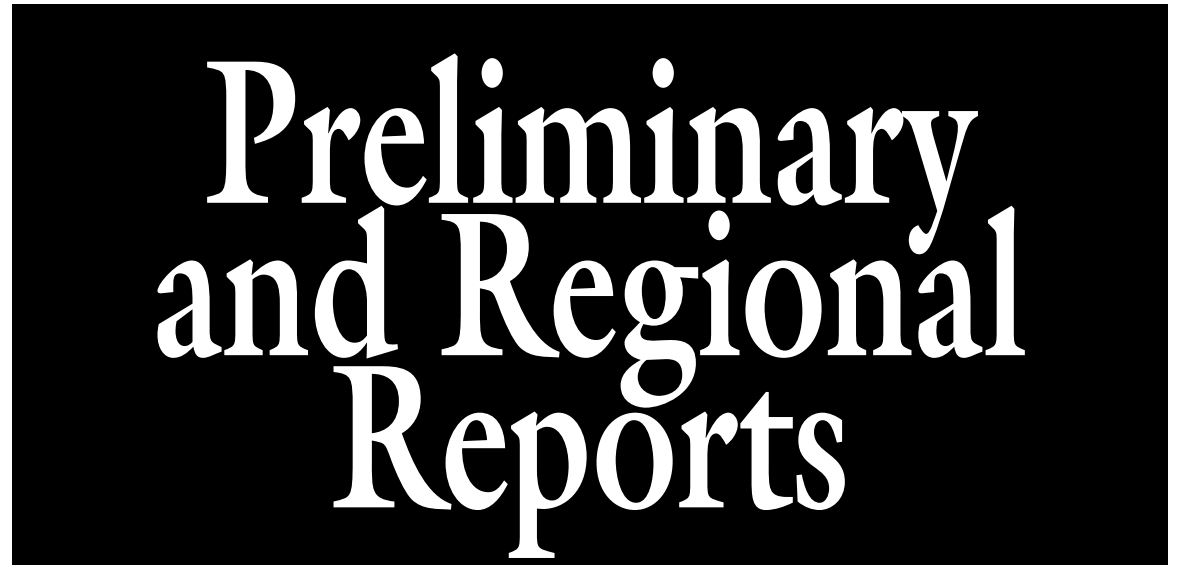

\section{Native and Non-native Shrub Post-transplant Performance under Low-volume Irrigation in Three Hardiness Zones}

\author{
A.L. Shober ${ }^{1,6}$, K.A. Moore ${ }^{2}$, C. Wiese ${ }^{3}$, S.M. Scheiber ${ }^{4}$, \\ E.F. Gilman ${ }^{5}$, and M. Paz ${ }^{3}$
}

ADDITIONAL INDEX WORDS. water management, landscape, canopy growth

SumMARY. Previous research on \#3 nursery container-grown shrubs suggests that some common shrub species could be established in the Florida landscape under natural rainfall when irrigated with $3 \mathrm{~L}$ of water every 4 days in U.S. Department of Agriculture hardiness zones $8 \mathrm{~b}$ and $9 \mathrm{a}$ or every 2 days in zone $10 \mathrm{~b}$ until first roots reached the canopy edge $(\approx 20$ weeks after planting). The current study evaluated the effects of these irrigation frequency recommendations on plant vigor, canopy growth, root growth, and aesthetic quality of 21 common landscape shrub species (10 Florida native and 11 non-native) planted in Florida in zones 8b, 9a, or $10 b$. Data suggests that it may be appropriate to adopt the 20 -week low-volume irrigation recommendations for the establishment of a wide variety of containergrown Florida native and non-native shrubs. However, Florida native and nonnative shrubs should be monitored for symptoms of drought stress for 2 years after planting.

The work was supported by the Florida Agricultural Experiment Station, the Florida Department of Agriculture and Consumer Services, the South Florida Water Management District, the Southwest Florida Water Management District, the St. Johns River Water Management District, and the Florida Nursery, Growers, and Landscape Association.

${ }^{1}$ Assistant Professor, University of Florida, IFAS, Center for Landscape Conservation and Ecology, Soil and Water Science Department, Gulf Coast REC, 14625 CR 672, Wimauma, FL 33598

${ }^{2}$ Associate Professor, University of Florida, IFAS, Environmental Horticulture Department, Ft. Lauderdale REC, 3205 College Avenue, Davie, FL 33314

${ }^{3}$ Biological Scientist, University of Florida, IFAS, Environmental Horticulture Department, $100 \mathrm{Mehr}$ hof Hall, P.O. Box 110675, Gainesville, FL 32611

${ }^{4}$ Assistant Professor, University of Florida, IFAS, Environmental Horticulture Department, MREC, 2725 Binion Road, Apopka, FL 32703

${ }^{5}$ Professor, University of Florida, IFAS, Environmental Horticulture Department, 100 Mehrhof Hall, P.O. Box 110675, Gainesville, FL 32611

${ }^{6}$ Corresponding author. E-mail: alshober@ufl.edu.
$\mathrm{U}$ rban population growth and periodic droughts throughout much of the United States have led to increased restrictions on landscape water use. These water restrictions have increased interest in planting native shrub species because natives are often touted as having lower water needs than non-native ornamental species (Bodle, 2001; Haehle, 2004; Hostetler et al., 2003). However, there are few studies that support that assertion. In fact, research indicates that water use is more likely to be a function of endemic habitat (Scheiber et al., 2008), shrub morphology (King and Wilson, 2006), plant growth rate (Fitzpatrick, 1983), and shrub maturity (Stabler and Martin, 2000) than its native range. For example, Scheiber et al. (2008) reported no differences in growth response or aesthetic appearance due to irrigation treatment for 8 of 10 native and 8 of 10 non-native species grown in northern Florida. Only two species, which were endemic to swamps and streams, showed increased growth in response to irrigation compared with no irrigation (Scheiber et al., 2008).

Previous research conducted at the University of Florida suggested that burford holly (Ilex cornuta 'Burfordii Nana'), pittosporum (Pittosporum tobira 'Variegata') (Wiese et al., 2009), and sweet viburnum (Viburnum odoratissimum) (Shober et al., 2009) could be established in the Florida landscape under natural rainfall in U.S. Department of Agriculture (USDA) hardiness zones $8 \mathrm{~b}$ and 9 a when irrigated with $3 \mathrm{~L}$ every $8 \mathrm{~d}$. Similarly, research suggested that wild coffee (Psychotria nervosa), copperleaf (Acalypha wilkesiana), orange jasmine (Murraya paniculata 'Lakeview') (Moore et al., 2009), and sweet viburnum (Shober et al., 2009) could be established in the Florida landscape under natural rainfall in zone $10 \mathrm{~b}$ with $3 \mathrm{~L}$ of supplemental irrigation applied every $4 \mathrm{~d}$ until roots reached the canopy edge. These studies also suggested that increasing the irrigation frequency from every $8 \mathrm{~d}$ to every $4 \mathrm{~d}$ in zones $8 \mathrm{~b}$ and $9 \mathrm{a}$, and from every $4 \mathrm{~d}$ to every $2 \mathrm{~d}$ in zone $10 \mathrm{~b}$ could improve plant vigor. The objective of this study was to evaluate the effects of these irrigation frequency recommendations on plant vigor, canopy growth, root growth, and aesthetic quality of 10 Florida native and 11 non-native shrub species planted in three hardiness zones.

\begin{tabular}{llll}
\hline $\begin{array}{l}\text { Units } \\
\begin{array}{l}\text { To convert U.S. to SI, } \\
\text { multiply by }\end{array}\end{array}$ & U.S. unit & SI unit & $\begin{array}{l}\text { To convert SI to U.S., } \\
\text { multiply by }\end{array}$ \\
\hline 0.3048 & $\mathrm{ft}$ & $\mathrm{m}$ & 3.2808 \\
0.0283 & $\mathrm{ft}^{3}$ & $\mathrm{~m}^{3}$ & 35.3147 \\
3.7854 & gal & $\mathrm{L}$ & 0.2642 \\
2.54 & inch $(\mathrm{es})$ & $\mathrm{cm}$ & 0.3937 \\
$\left({ }^{\circ} \mathrm{F}-32\right) \div 1.8$ & ${ }^{\circ} \mathrm{F}$ & ${ }^{\circ} \mathrm{C}$ & $\left(1.8 \times{ }^{\circ} \mathrm{C}\right)+32$
\end{tabular}


Table 1. Ten Florida native and 11 non-native species planted in U.S. Department of Agriculture hardiness zones 8b, 9a, and $10 \mathrm{~b}$ to evaluate a reduced irrigation frequency scheme for establishment of shrubs after transplant into the landscape.

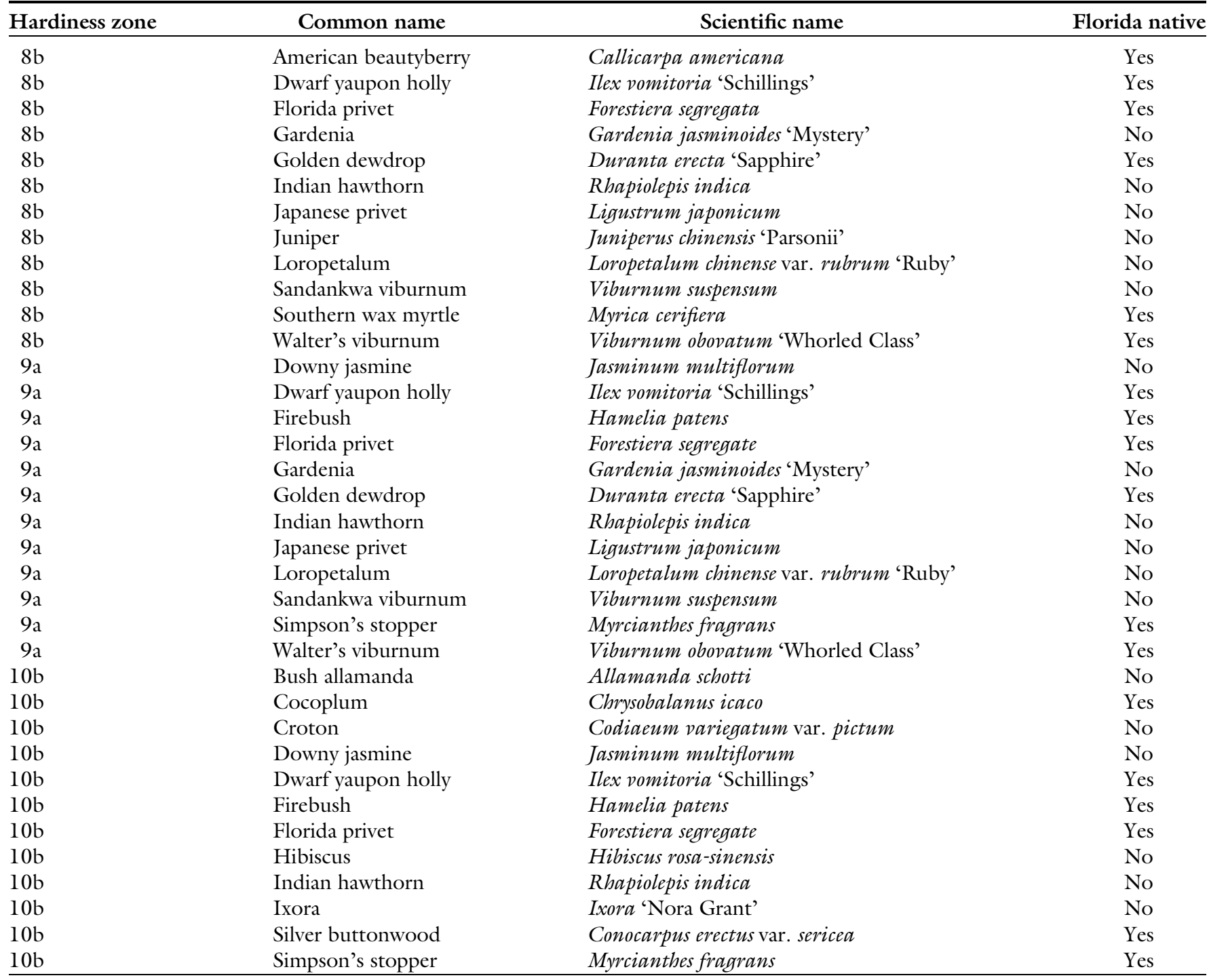

\section{Materials and methods}

EXPERIMENTAL DESIGN. Six native and six non-native species (Table 1 ) were obtained from a commercial nursery in \#3 smooth-sided nursery containers and were planted at three sites in Florida: 1) Plant Science Research and Education Unit located in USDA hardiness zone 8b (Citra, FL; Arredondo sand), 2) Gulf Coast Research and Education Center located in zone 9a (Balm, FL; Zolfo fine sand or Seffner fine sand), and 3) Fort Lauderdale Research and Education Center located in zone 10b (Fort Lauderdale, FL; Margate fine sand). Shrubs appropriate for each site climate were selected from a total of 21 shrub species (10 Florida native and 11 non-native) (Table 1 ). Six replicates of each shrub species were planted into level plots at each site. Shrubs were installed on the two following planting dates at each site: Dec. 2006 (USDA hardiness zones $8 \mathrm{a}$ and $10 \mathrm{~b}$ ) or Dec. 2007 (zone 9a), and June 2007 (zones 8a, 9a, and 10b) as outlined in Shober et al. (2009). Shrubs were grouped in the field by planting date. The average minimum temperature at $2 \mathrm{~m}$ above the soil surface collected for each 52-week planting period from the Florida Automated Weather Network stations located within $50 \mathrm{~m}$ of the planting sites was as follows: 21.81 and $38.20^{\circ} \mathrm{F}$ in zones $8 \mathrm{a}$ and $10 \mathrm{~b}$, respectively (Dec. 2007); $25.24,27.35$, and $37.21^{\circ} \mathrm{F}$ in zones $8 \mathrm{a}$, $9 \mathrm{a}$, and $10 \mathrm{~b}$, respectively (June 2007); and $27.35^{\circ} \mathrm{F}$ in zone $9 \mathrm{a}$ (Dec. 2007).

Irrigation treatments were applied, regardless of rainfall events, to six plant replicates at each location for each planting date with the following frequencies: every $2 \mathrm{~d}$ in hardiness zone $10 \mathrm{~b}$ and every $4 \mathrm{~d}$ in zones $8 \mathrm{~b}$ and 9a. Irrigation treatments were selected based on recommendations for vigor that were developed by evaluating irrigation frequencies for burford holly and pittosporum grown in zones $8 \mathrm{~b}$ and 9a (Wiese et al., 2009), for wild coffee, copperleaf, and orange jasmine grown in zone $10 \mathrm{~b}$ (Moore et al., 2009), and for sweet viburnum grown in all three zones (Shober et al., 2009). Each shrub was irrigated with $3 \mathrm{~L}$ of water per irrigation event applied to the root ball using three bubbler emitters (Shrubbler ${ }^{\circledR} 360^{\circ}$; Antelco ${ }^{\circledR}$, Longwood, FL). Each emitter was mounted 4 inches above ground level with an emitter located 
Table 2. Median visual density and dieback (quality) ratings $(n=6)$ for selected Florida native and non-native shrub species established in the landscape under low-volume [3 L $(0.8$ gal $)$ per plant] irrigation over two planting dates in U.S.

Department of Agriculture hardiness zones 8b, 9a, and $10 \mathrm{~b}$.

\begin{tabular}{|c|c|c|c|c|c|c|c|c|c|}
\hline \multirow[b]{2}{*}{ Species } & \multirow[b]{2}{*}{ Planting date } & \multicolumn{4}{|c|}{ Density $(1-9 \text { scale })^{z}$} & \multicolumn{4}{|c|}{ Dieback (1-9 scale $)^{\mathrm{z}}$} \\
\hline & & $12 \mathrm{WAT}^{\mathrm{y}}$ & 20 WAT & 28 WAT & 52 WAT & $12 \mathrm{WAT}$ & $20 \mathrm{WAT}$ & 28 WAT & 52 WAT \\
\hline & & \multicolumn{8}{|c|}{ Hardiness zone $8 b$} \\
\hline Dwarf yaupon holly & Dec. 2006 & 9 & 8 & 9 & 9 & 9 & 9 & 9 & 9 \\
\hline Florida privet & Dec. 2006 & 1 & 8 & 6 & 9 & 7 & 8 & 6 & 9 \\
\hline Gardenia & Dec. 2006 & 9 & 8 & 4 & 9 & 9 & 8 & 4 & 9 \\
\hline Japanese privet & Dec. 2006 & 9 & 9 & 9 & 9 & 9 & 9 & 9 & 9 \\
\hline Juniper & Dec. 2006 & 9 & 9 & 9 & 9 & 8 & 8 & 8 & 9 \\
\hline Loropetalum & Dec. 2006 & 9 & 9 & 8 & 9 & 9 & 9 & 8 & 9 \\
\hline Sandankwa viburnum & Dec. 2006 & 9 & 9 & 8 & 9 & 9 & 9 & 8 & 9 \\
\hline Southern wax myrtle & Dec. 2006 & 9 & 8 & 9 & 9 & 9 & 9 & 9 & 9 \\
\hline Gardenia & June 2007 & 9 & 9 & 9 & 7 & 9 & 9 & 9 & 7 \\
\hline Golden dewdrop & June 2007 & 9 & 8 & 2 & 2 & 9 & 8 & 3 & 2 \\
\hline Indian hawthorn & June 2007 & 9 & 9 & 9 & 9 & 9 & 8 & 9 & 9 \\
\hline Japanese privet & June 2007 & 9 & 9 & 9 & 8 & 9 & 9 & 9 & 8 \\
\hline Juniper & June 2007 & 9 & 9 & 9 & 9 & 9 & 9 & 8 & 9 \\
\hline Loropetalum & June 2007 & 9 & 8 & 8 & 8 & 8 & 8 & 8 & 8 \\
\hline Sandankwa viburnum & June 2007 & 9 & 9 & 9 & 8 & 8 & 9 & 9 & 7 \\
\hline Southern wax myrtle & June 2007 & 9 & 9 & 9 & 9 & 9 & 8 & 9 & 9 \\
\hline \multirow[t]{2}{*}{ Walter's viburnum } & June 2007 & 8 & 7 & 7 & 6 & 9 & 8 & 7 & 7 \\
\hline & & \multicolumn{8}{|c|}{ Hardiness zone $9 a$} \\
\hline Downy jasmine & June 2007 & 9 & 9 & 9 & 9 & 9 & 9 & 9 & 9 \\
\hline Sandankwa viburnum & June 2007 & 9 & 8 & 8 & 9 & 8 & 8 & 8 & 9 \\
\hline Simpson’s stopper & June 2007 & 9 & 9 & 9 & 9 & 8 & 9 & 9 & 9 \\
\hline Walter's viburnum & June 2007 & 9 & 9 & 7 & 9 & 8 & 7 & 5 & 9 \\
\hline Downy jasmine & June 2007 & 8 & 8 & 9 & 9 & 8 & 8 & 9 & 9 \\
\hline Dwarf yaupon holly & Dec. 2007 & 9 & 9 & 9 & 9 & 9 & 9 & 9 & 9 \\
\hline Firebush & Dec. 2007 & 3 & 9 & 9 & 3 & 2 & 9 & 9 & 4 \\
\hline Florida privet & Dec. 2007 & 7 & 8 & 8 & 5 & 8 & 9 & 9 & 5 \\
\hline Gardenia & Dec. 2007 & 7 & 9 & 9 & 8 & 8 & 9 & 9 & 8 \\
\hline Golden dewdrop & Dec. 2007 & 9 & 9 & 9 & 8 & 9 & 9 & 9 & 8 \\
\hline Indian hawthorn & Dec. 2007 & 9 & 8 & 9 & 9 & 9 & 9 & 9 & 9 \\
\hline Japanese privet & Dec. 2007 & 8 & 8 & 8 & 6 & 9 & 8 & 8 & 7 \\
\hline Loropetalum & Dec. 2007 & 9 & 8 & 8 & 7 & 9 & 8 & 8 & 6 \\
\hline Sandankwa viburnum & Dec. 2007 & 8 & 7 & 7 & 7 & 8 & 8 & 8 & 7 \\
\hline Simpson's stopper & Dec. 2007 & 9 & 9 & 9 & 9 & 9 & 9 & 9 & 8 \\
\hline \multirow[t]{2}{*}{ Walter's viburnum } & Dec. 2007 & 9 & 9 & 9 & 8 & 9 & 9 & 9 & 7 \\
\hline & & \multicolumn{8}{|c|}{ Hardiness zone $10 b$} \\
\hline Bush allamanda & Dec. 2006 & 7 & 8 & 7 & 3 & 7 & 7 & 7 & 3 \\
\hline Cocoplum & Dec. 2006 & 7 & 7 & 8 & 7 & 7 & 8 & 8 & 8 \\
\hline Croton & Dec. 2006 & 7 & 8 & 8 & 7 & 8 & 9 & 9 & 7 \\
\hline Downy jasmine & Dec. 2006 & 8 & 8 & 9 & 8 & 8 & 9 & 9 & 9 \\
\hline
\end{tabular}

(Continued on next page) 
Table 2. (Continued) Median visual density and dieback (quality) ratings $(n=6)$ for selected Florida native and non-native shrub species established in the landscape under low-volume [ $3 \mathrm{~L}(0.8 \mathrm{gal})$ per plant] irrigation over two planting dates in U.S. Department of Agriculture hardiness zones 8b, 9a, and $10 b$.

\begin{tabular}{|c|c|c|c|c|c|c|c|c|c|}
\hline \multirow[b]{2}{*}{ Species } & \multirow[b]{2}{*}{ Planting date } & \multicolumn{4}{|c|}{ Density $(1-9 \text { scale })^{\mathrm{z}}$} & \multicolumn{4}{|c|}{ Dieback $(1-9 \text { scale })^{\mathrm{z}}$} \\
\hline & & 12 WAT $^{y}$ & $20 \mathrm{WAT}$ & 28 WAT & 52 WAT & 12 WAT & $20 \mathrm{WAT}$ & $28 \mathrm{WAT}$ & $52 \mathrm{WAT}$ \\
\hline & & \multicolumn{8}{|c|}{ Hardiness zone $10 b$ continued } \\
\hline Firebush & Dec. 2006 & 7 & 7 & 8 & 7 & 8 & 8 & 8 & 7 \\
\hline Florida privet & Dec. 2006 & 7 & 8 & 8 & 8 & 7 & 8 & 9 & 9 \\
\hline Hibiscus & Dec. 2006 & 8 & 8 & 9 & 8 & 8 & 9 & 9 & 9 \\
\hline Silver buttonwood & Dec. 2006 & 7 & 8 & 7 & 8 & 7 & 9 & 8 & 8 \\
\hline Simpson's stopper & Dec. 2006 & 7 & 7 & 7 & 7 & 8 & 8 & 8 & 7 \\
\hline Bush allamanda & June 2007 & 7 & 8 & 8 & 9 & 7 & 8 & 8 & 9 \\
\hline Cocoplum & June 2007 & 7 & 7 & 8 & 9 & 8 & 8 & 8 & 9 \\
\hline Croton & June 2007 & 7 & 8 & 8 & 7 & 8 & 8 & 8 & 8 \\
\hline Hibiscus & June 2007 & 7 & 7 & 7 & 8 & 8 & 8 & 8 & 9 \\
\hline Indian hawthorn & June 2007 & 8 & 7 & 8 & 9 & 8 & 8 & 8 & 9 \\
\hline Ixora & June 2007 & 7 & 7 & 8 & 9 & 8 & 8 & 8 & 9 \\
\hline Silver buttonwood & June 2007 & 8 & 8 & 8 & 9 & 8 & 8 & 8 & 9 \\
\hline Simpson's stopper & June 2007 & 8 & 8 & 7 & 7 & 8 & 8 & 8 & 8 \\
\hline
\end{tabular}

${ }^{\mathrm{z}} 1$ = dead plant; 9 = dense, full canopy with no dieback.

${ }^{y} \mathrm{WAT}=$ weeks after transplant.

$x_{-}=$plant was not available for measurement due to freeze damage or plant death.

on the east and west side of each plant, 6 inches from the outside of the root ball, and the third emitter was positioned on the root ball. Irrigation frequencies were controlled as separate zones as described by Shober et al. (2009). Irrigation was ended 20 weeks after transplant, after which time supplemental irrigation ( $3 \mathrm{~L}$ per plant by hand) was supplied to all shrubs for a specific planting date over the 2 -year post-planting period when signs of severe water stress, such as severe foliage wilting, were observed.

Plant Quality and GRowTH InDEX. Plant quality (plant density and dieback) was visually rated on a scale of 1 (dead plant) to 9 (dense, full canopy with no dieback) at 12 , 20, 28, and 52 weeks after transplant (WAT). Growth index (GI) was used as a quantitative indicator of plant growth. GI in cubic meters for each plant was calculated as: $\mathrm{GI}=\mathrm{H} \times \mathrm{Wl} \times$ W2, where $\mathrm{H}$ is the plant height (meters), Wl is the widest width of the plant (meters), and W2 is the width perpendicular to the widest width (meters). Growth index was measured on three plant replicates per treatment at 0 (date of planting), $12,20,28$, and 52 WAT.
ROOT-TO-CANOPY SPREAD RATIO. Root spread was measured on three plant replicates per irrigation frequency at 12, 20, 28, and 52 WAT by excavating the longest root (near the soil surface) on the east and west side of the plant and measuring its length from the base of the plant. Root spread radius was calculated as the mean of the east and west root lengths. Root-to-canopy spread ratio was then calculated as: root spread radius/mean canopy radius with mean canopy radius $=1 / 4 \times(\mathrm{Wl}+\mathrm{W} 2)$.

Data analysis. Experimental design and data structure required that statistical analysis of growth and quality data be limited to descriptive statistics (mean, median, etc.). Therefore, median values were used to describe the effect of the selected irrigation treatment on plant quality ratings and mean values were used to describe the effects of the selected irrigation treatment on canopy and root growth for shrub species planted in each hardiness zone.

\section{Results and discussion}

Plant Quality and growth INDEX. All plants, with the exception of golden dewdrop (Duranta erecta 'Sapphire') in zone 8b and gardenia
(Gardenia jasminoides 'Mystery') in zone 9a, survived and were actively growing 52 WAT when watered with $3 \mathrm{~L}$ of water every $4 \mathrm{~d}$ (zones $8 \mathrm{~b}$ and $9 \mathrm{a}$ ) or every $2 \mathrm{~d}$ (zone $10 \mathrm{~b}$ ) for 20 WAT (Tables 2 and 3 ). In addition, most shrub species maintained high plant quality ratings (i.e., density and dieback) (Table 2). Poor performance of some species was not related to water stress. For example, gardenia planted in zone 9a was plagued by nutrient deficiencies that were related to pockets of alkaline soil ( $\mathrm{pH}$ near 8.0) in the field (Tables 2 and 3 ). In addition, some species [firebush (Hamelia patens) in zones $8 \mathrm{~b}$ and 9a, golden dewdrop in zone 8b] suffered a decline in growth and quality due to freeze damage.

Our data also suggest that there were no differences in canopy growth or aesthetic quality of native versus non-native shrubs at any of the planting locations (Tables 2 and 3 ). Our results are similar to those of Scheiber et al. (2008), who found that neither native species nor non-native species were, as a group, more responsive to irrigation. Scheiber et al. (2008) reported that growth of two of 10 Florida natives and two of 10 


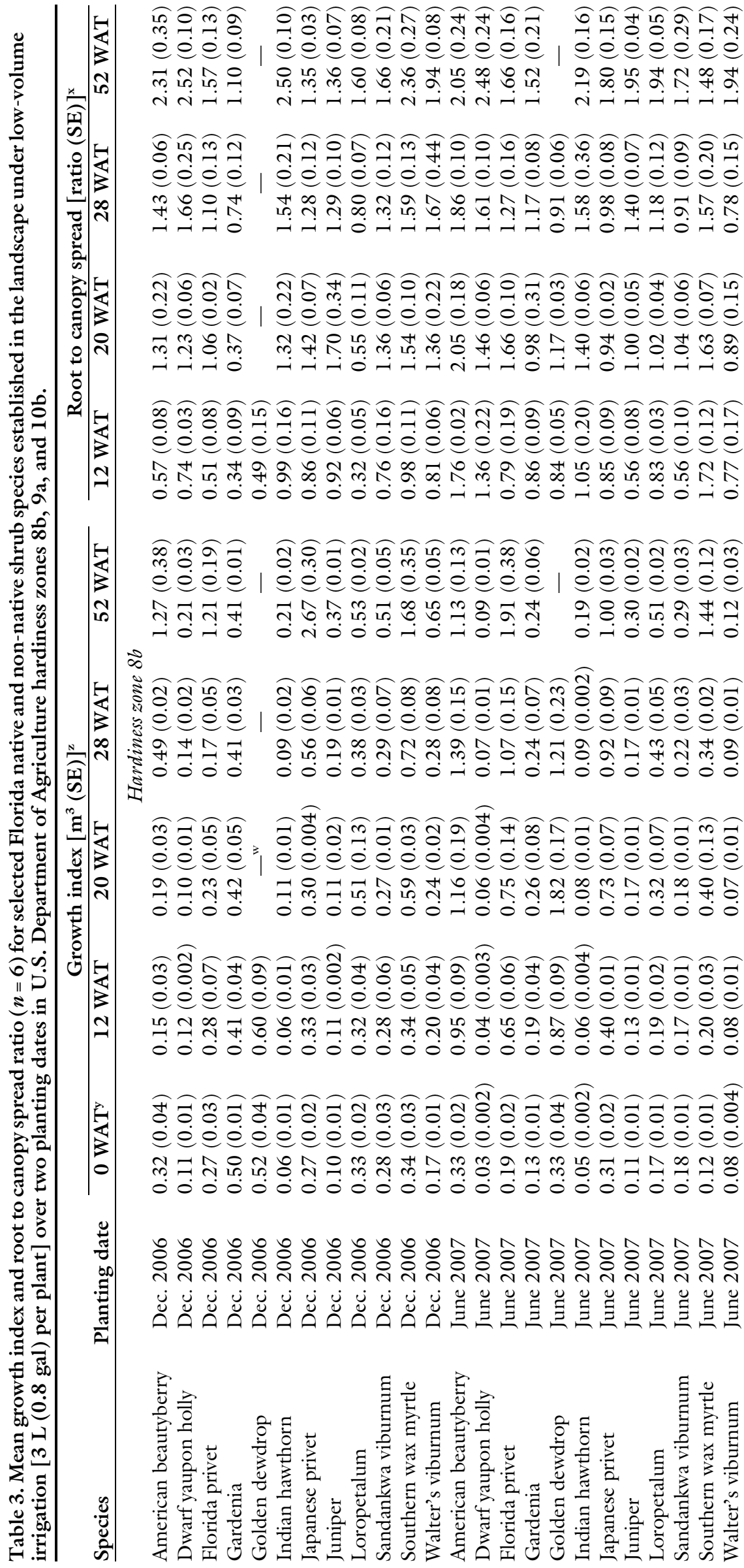

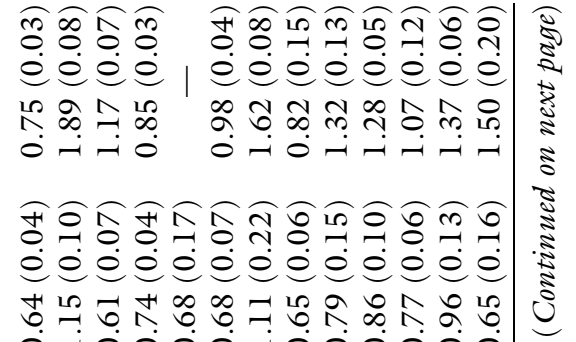

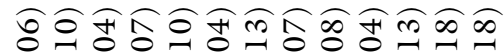
e e eje eje ejejo 的各䓃 0000000000000

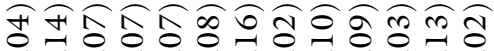
jejejejejejej

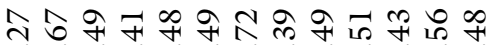
0000000000000

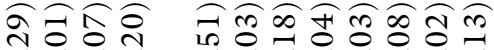
e ejél|

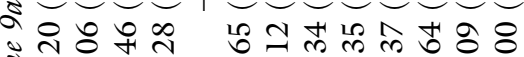

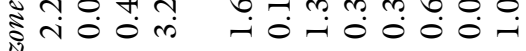
औ

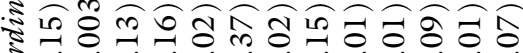
sejejejejejeje

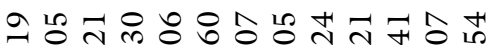

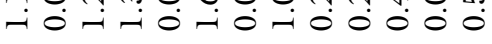

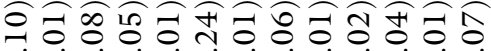
éejeje eje ejee

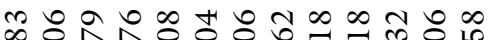
$00000-10000000$

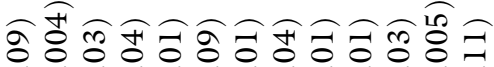
ejejejejejeje 的苛阐 0000000000000

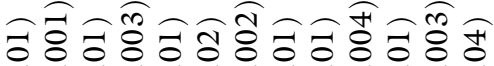
ejejejejejejej

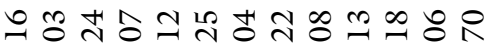
0000000000000

ôें

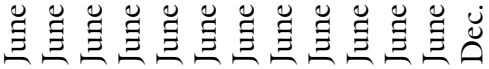

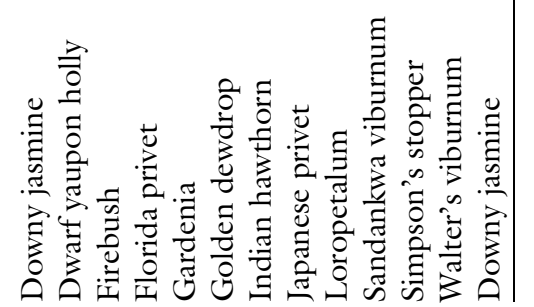




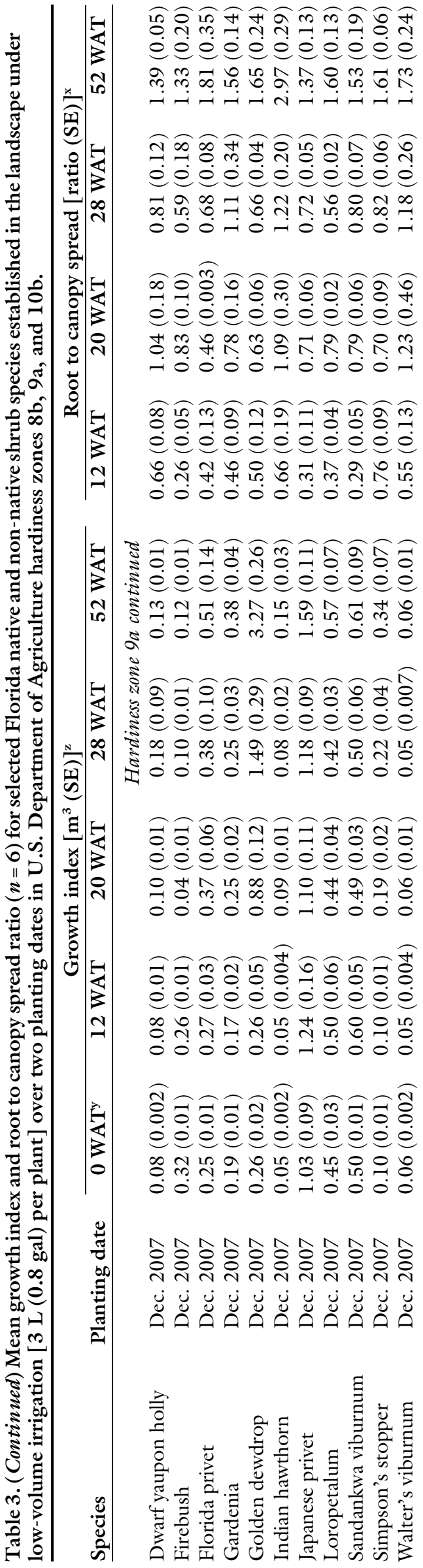

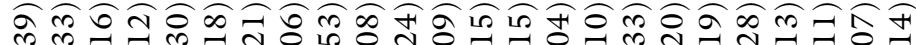

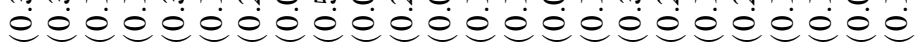

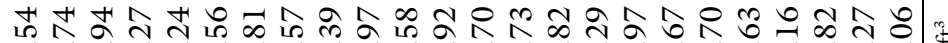

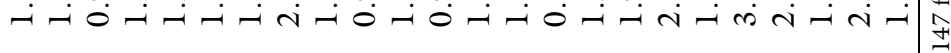

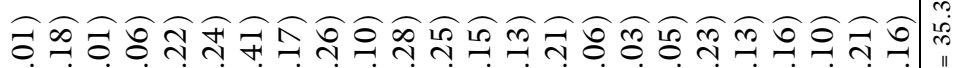

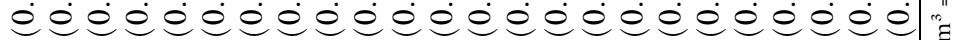
ฤำำ ن

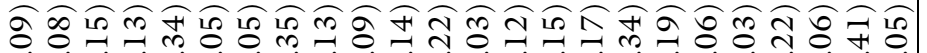

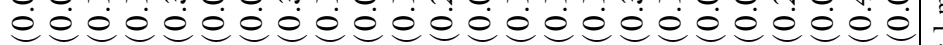

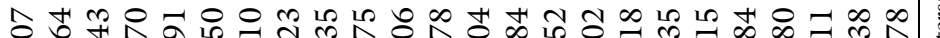

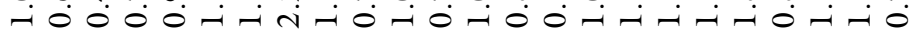

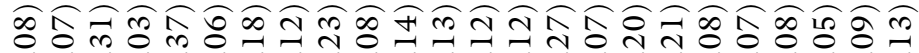

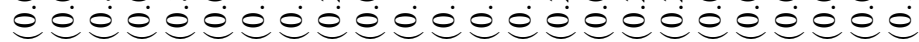

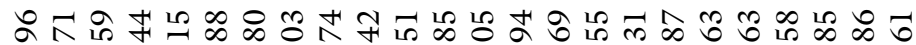

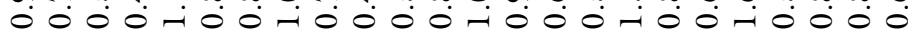

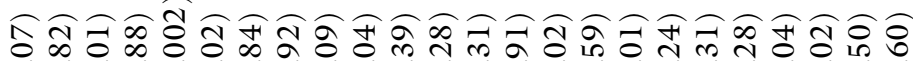

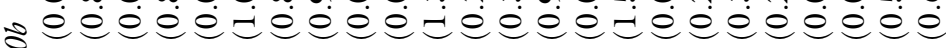

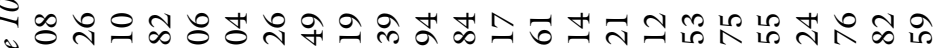
है

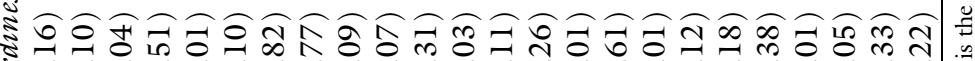

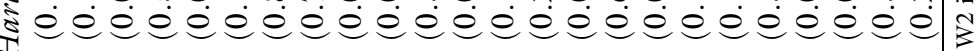

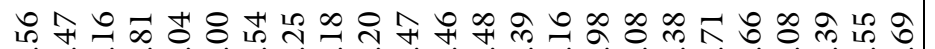
$000-0-40000-10-1000-100-0$

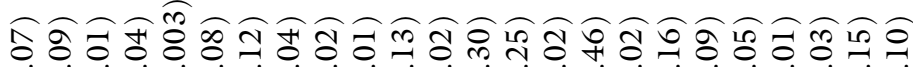

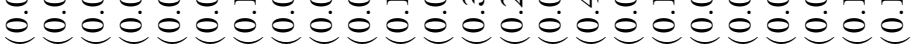

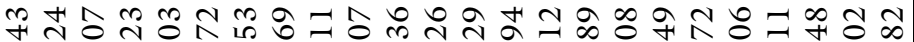
$000-100000000$ - 00 - 000 - 00 -

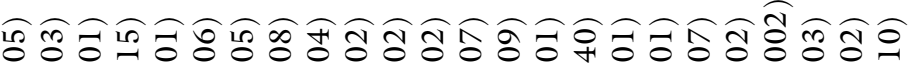

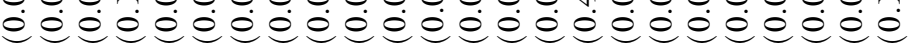

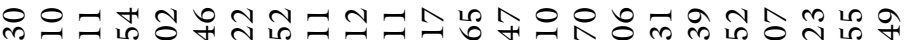
$000000000000000-10000000$

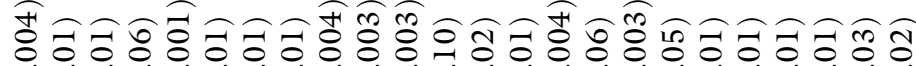

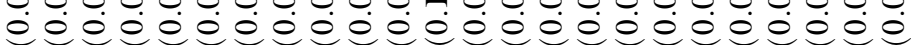

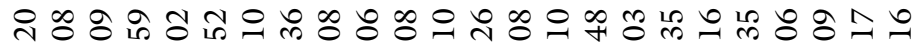
000000000000000000000000

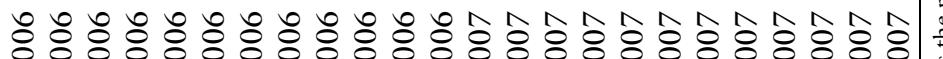

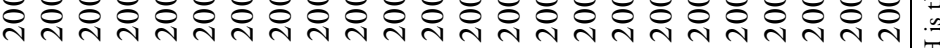

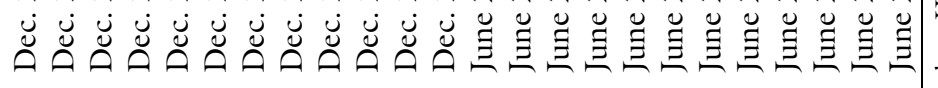


non-natives increased when irrigated (daily for $17 \mathrm{~d}$, then every $2 \mathrm{~d}$ for 7 weeks, then every 7 d). Enhanced growth of irrigated shrubs seemed to be associated with species habitat preference because all species that increased in growth as a response to irrigation were endemic to wet habitats (e.g., swamps and streams) (Scheiber et al., 2008).

ROOT SPREAD-TO-CANOPY SPREAD RATIO. Most shrub species evaluated, regardless of geographic origin, approached a root spread-tocanopy spread ratio of 1.0 by 28 WAT and had exceeded 1.0 by 52 WAT. The majority of shrubs planted in zones $8 \mathrm{~b}$ and $10 \mathrm{~b}$ had reached a ratio of 1.0 by 20 WAT, which corresponds to the time when irrigation was discontinued. Root spread-to-canopy spread ratio of tree species has been reported to be species dependent (Gilman and Kane, 1991; Kummerow et al., 1977; Rogers, 1934; Rogers and Vyvyan, 1934), but roots generally extended two to three times the distance from trunk to drip line on established nursery-grown trees (Rogers, 1934; Rogers and Vyvyan, 1934) and 1.7 to 3.7 times the drip line for shrubs (Gilman and Kane, 1991). Shrubs may be considered fully established when the root spread-to-canopy spread ratio has stabilized (Gilman and Kane, 1991). Root spread-to-canopy spread ratio of all shrubs evaluated continued to increase throughout the 52 -week period of study, which suggests that shrubs, although not fully established, were able to compensate for evapotranspiration losses without additional irrigation under normal or greater rainfall conditions.

Results of our study show that additional shrub species can be established in the predominantly sandy soils of the Florida landscape in USDA hardiness zones $8 \mathrm{~b}, 9 \mathrm{a}$, and $10 \mathrm{~b}$ when following the irrigation recommendations for plant vigor published by
Shober et al. (2009), Moore et al. (2009), and Wiese et al. (2009). A total of 21 commonly planted native and non-native landscape shrubs was established using these procedures. Despite the public perception of an increased drought tolerance of native shrubs, our research suggests that there were no differences in irrigation needs based solely on native range. This suggests that it may be appropriate to adopt the 20-week low-volume irrigation recommendations for the establishment of a wide variety of Florida native and non-native shrubs. The ability to adopt the 20 -week lowvolume irrigation recommendations for native and non-native landscape shrubs will provide the industry with greater choice of plant material, while continuing to conserve valuable water resources. However, Florida native and non-native shrubs should be monitored for symptoms of drought stress for 2 years after planting.

\section{Literature cited}

Bodle, M. 2001. Waterwise south Florida landscapes. South Florida Water Management District, West Palm Beach, FL.

Fitzpatrick, G. 1983. Relative water demand in container-grown ornamental plants. HortScience 18:760-762.

Gilman, E.F. and M.E. Kane. 1991. Growth dynamics following planting of cultivars of Juniperus chinensis. J. Amer. Soc. Hort. Sci. 116:637-641.

Haehle, R. 2004. Native Florida plants: Low maintenance landscaping and gardening. Taylor Trade Publishing, Lanham, MD.

Hostetler, M., G. Klowden, S. Miller, and K. Youngentob. 2003. Landscaping backyards for wildlife: Top ten tips for success. 24 Nov. 2009. <http://edis.ifas.ufl.edu/ uw175>.

King, W.M. and J.B. Wilson. 2006. Differentiation between native and exotic plant species in a dry grassland: Realized responses to perturbation, and comparison with fundamental responses. Austral Ecol. 31:984-995.

Kummerow, J., D. Krause, and W. Jow. 1977. Root systems of chaparral shrubs. Oecologia 29:163-177.

Moore, K.A., A.L. Shober, E.F. Gilman, C. Wiese, S.M. Scheiber, M. Paz, and M.M. Brennan. 2009. Post-transplant growth of container-grown wild coffee, copperleaf, and orange jasmine is affected by irrigation frequency. HortTechnology 19:786-791.

Rogers, W.S. 1934. Root studies III. Pears, gooseberry and black currant root systems under different soil fertility conditions with some observation on root stock and scion effect in pears. J. Pomol. Hort. Sci. 11:1-18.

Rogers, W.S. and M.C. Vyvyan. 1934. Root studies V. Root stock and soil effect of apple root systems. J. Pomol. Hort. Sci. 12:110-150.

Scheiber, S.M., E.F. Gilman, D.R. Sandrock, M. Paz, C. Wiese, and M.M. Brennan. 2008. Postestablishment landscape performance of Florida native and exotic shrubs under irrigated and nonirrigated conditions. HortTechnology 18:59-67.

Shober, A.L., K.A. Moore, C. Wiese, S.M. Scheiber, E.F. Gilman, M. Paz, M.M. Brennan, and S. Vyapari. 2009. Posttransplant irrigation frequency affects growth of container-grown sweet viburnum in three hardiness zones. HortScience 44:1683-1687.

Stabler, L.B. and C.A. Martin. 2000. Irrigation regimens differentially affect growth and water use efficiency of two southwest landscape plants. J. Environ. Hort. 18:66-70.

Wiese, C.L., A.L. Shober, E.F. Gilman, M. Paz, K.A. Moore, S.M. Scheiber, M.M. Brennan, and S. Vyapari. 2009. Effects of irrigation frequency during establishment on growth of Ilex cornuta 'Burfordii Nana' and Pittosporum tobira 'Variegata'. HortScience 44:1438-1443. 